\title{
Environmental protection, energy policy and poverty reduction synergies of an integrated approach
}

\section{Working Paper}

Author(s):

Schubert, Renate; Blasch, Julia; Hoffmann, Kristin

Publication date:

2008

Permanent link:

https://doi.org/10.3929/ethz-a-005830172

Rights / license:

In Copyright - Non-Commercial Use Permitted

Originally published in:

IED working paper 1 


\section{Environmental Protection, Energy Policy and Poverty Reduction - Synergies of an Integrated Approach}

Renate Schubert, Julia Blasch, Kristin Hoffmann

Institute for Environmental Decisions, Chair of Economics 



\title{
Environmental Protection, Energy Policy and Poverty Reduction - Synergies of an Integrated Approach
}

\author{
Renate Schubert, Julia Blasch, Kristin Hoffmann
}

ETH Zurich, Institute for Environmental Decisions, Chair of Economics, Weinbergstrasse 35, CH-8092 Zurich

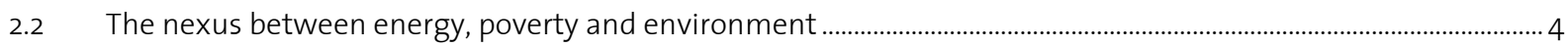

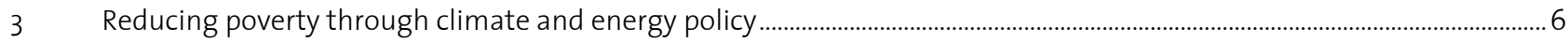

$3.1 \quad$ Mainstreaming and integrating policies............................................................................................................................... 6

3.2 Mitigating climate change through the Kyoto mechanisms .................................................................................................

3.3 Improving access to advanced energy in developing countries........................................................................................... 8

3.4 Promoting adaptation to reduce vulnerability ………..................................................................................................... 8

3.5 Positive feedback of poverty reduction on environmental protection.................................................................................

$4 \quad$ Financing climate change and sustainable development .......................................................................................................................

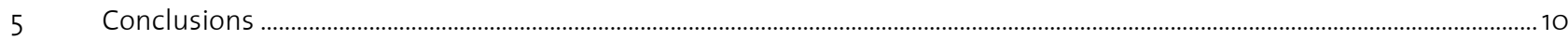


Abstract: This paper describes the mechanisms that link poverty reduction with climate and energy policy. First, there is a brief analysis of the relationship between ongoing climate change, energy use and poverty. This analysis is followed by an overview of different policy options that have the potential to fight poverty while simultaneously limiting global warming and environmental degradation. Mitigating climate change, transforming the energy systems in developing countries and financing adaptation to climate change are pointed out as central policy fields governments and developing agencies should focus on. Furthermore, one can argue that new technologies to increase energy efficiency and the dissemination of renewable energy systems have an especially strong impact on poverty. Access to clean and cost-efficient energy has a direct effect on the income generation potentials of the poor. Finally, this paper identifies appropriate financing mechanisms to implement the aforementioned strategies.

\section{$1 \quad$ Poverty reduction and environmental protection as key challenges}

At the start of the 21st century, fighting poverty and protecting the environment are two of the most urgent challenges the international community is faced with (UN, 2000). The idea of integrating environmental protection policies with poverty reduction strategies to increase synergies is by no means a new one. During the Earth Summit in Rio de Janeiro in 1992 United Nations member states already agreed on mainstreaming and integrating climate responses with development and poverty eradication processes. This idea was taken up again in the declaration of the Millennium Development Goals (MDGs) in 2000 and its reinforcement at the Earth Summits in Johannesburg ("Johannesburg Plan of Implementation", 2002) and New York (2005).

However, little progress has been made in putting such an integrated approach into practice: Even now, 1.1 billion people subsist on less than one US dollar a day; the same number of people has no access to safe drinking water, and around 840 million people are malnourished. At the same time human intervention in the natural environment is already jeopardizing the livelihood of the poor throughout the world. Moreover, the anticipated impacts of global climate change throughout the next decades will have an even more life-threatening impact in the future, especially in developing countries. These countries will be hit most intensely by rising temperatures and extreme weather events. Unless counter-measures are adopted, climate change will join as an addition on existing vulnerabilities, will pose a serious threat to poverty reduction and will undermine progress made in other fields towards achieving the MDGs (WBGU, 2005; UNDP et al., 2003).
In recent years, the need for more energy efficient technologies and the claim for the use of clean and renewable energy sources have gained weight on the political agenda, as consciousness rose that energy resources will run short in the light of a growing world population and that increasing carbon emissions boost global warming. The first international conference for renewable energies ("Renewables 2004") highlighted the contributions that renewable energies can make to world development. Even before, the 'OECD Environmental Strategy for the First Decade of the 21st Century' (2001) and the World Bank's, Environmental Strategy for the Energy Sector' (2000) integrated the three policy fields of environment, energy and poverty reduction. The fifteenth session of the United Nations Commission on Sustainable Development (CSD) in 2007 will focus on energy, discussed in a thematic cluster with industrial development, atmosphere/air pollution and climate change. All this shows that among policy makers a clear consensus emerges that sustainable energy policy can serve both environmental as well as development goals and should be regarded as an important 'link between' and 'multiplier for' environmental policy and poverty reduction.

This paper aims to point out benefits of an integrated approach. We argue for the strengthening of the link between environmental protection, energy supply and poverty reduction as well as for a more effective embedding of these areas in national and international policies. Climate change measures in particular should be addressed in development policy. We state that the separation of the three policy fields would run the risk of implementing conflicting policies that cannot adequately address global challenges ("develop first, clean later"approach). An integrated approach, however, would offer opportunities to make use of synergy and multiplier effects. 


\section{Global change, energy and poverty - impacts and interrelations}

\subsection{Poverty impacts of global change}

One of the most recent environmental threats is global climate change. Science tells us that global warming will bring about gradual changes such as rise in sea levels, shifts of climatic zones and changes in precipitation patterns. Besides these gradual changes an increase in frequency and magnitude of extreme weather events such as droughts, floods and storms is expected. Sea-level rise and the warming of our oceans, for example, are exposing coastal regions to mounting flood and hurricane risks (WBGU, 2006).

Climate change impacts will be distributed quite unevenly throughout the world's regions. It will have serious impacts on industrial and developing countries, with the latter suffering most from the expected increase in global surface temperatures. In those countries most of the people live from subsistence livelihoods that depend strongly on climate-sensitive factors (fisheries, forestry and agriculture). In addition, human, institutional and financial capacities for adaptation are limited. Thus, people are highly vulnerable to the regional impacts of climate change. Climate change will aggravate existing vulnerabilities. It will further reduce access to drinking water, negatively affect the health of poor people, and will pose a real threat to food security in many countries in Africa, Asia, and Latin America. In some areas where livelihood choices are limited, migration, a destabilization of affected societies and even conflicts are to be expected (WBGU, 2005). Taking these processes into account, climate change is likely to induce a downward poverty cycle through manifold interactions, as will be shown below.

Agriculture is particularly vulnerable to climatic change. Factors playing a role here include temperature change, the availability of water, the spread of plant and animal diseases, but also the effects of fertilization resulting from increased carbon dioxide concentrations in the atmosphere. In most developing countries the agricultural sector still employs most of the population and adds substantially to the countries' GDP (e.g. up to 59 per cent in Guinea-Bissau; WRI, 2003). Reductions in crop yields could lead to famine and undernourishment.

Furthermore, climate change is projected to reduce water availability in many water scarce regions, particularly in the subtropics, due to increased frequencies of droughts, increased evaporation, and changes in rainfall patterns and run-off (IPCC 2001b). Sea levels will rise, which can lead to salinization and loss of arable land and potable water supplies, imposing a vital threat to small island states in particular. Above all, in many African and Asian countries a considerable proportion of protein needs is met by fisheries. Rising water temperatures and changing ocean currents may have a negative impact on fish stocks, a situation which may lead to food shortages (IPCC, 2001a).

When addressing dangerous global warming, another major concern is health. The health impacts of climate change are particularly severe for those groups who have limited access to resources and technologies and whose infrastructure and institutions have a low degree of adaptive capacity (WHO, 2002). A study by the World Health Organization on health hazards caused by climate change in the year 2000 compared to the baseline scenario of 1961 to 1990 examined four threats: malaria, undernourishment, diarrhea and floods. The spread of vector-borne infectious diseases such as malaria depends greatly upon precipitation and temperature conditions. It is thus highly sensitive to climatic changes. IPCC (2001b) expects a growing number of people to be exposed to these diseases. Furthermore, the severity of these diseases would be increased by malnutrition due to the reduction in crop yields. Altogether the largest disease burden can be found in Sub-Saharan Africa and South Asia (WHO, 2001). The overall burden is estimated at 5.5 million DALYs (Disability-Adjusted Life Years) - as a measure of the loss of healthy or productive life years - of which only 8,000 DALYs or 0.15 per cent are assigned to the industrial countries (Campbell-Lendrum et al., 2003; WHO, 2002).

Extreme weather events like hurricanes and droughts are predicted to increase in frequency and severity. From 1992 to 2001 about 2,000 million people were affected by environmental disasters, 98 per cent of which were weather-related. Flood disasters alone affected 1,200 million people in Asia during this period. Of the 78,000 people killed by weather-related disasters, 58 per cent lived in the least developed countries and a further 39 percent in countries with medium levels of development (IFRC, 2002). Poor countries often lack the early warning systems and emergency services needed to warn the population in time of impending floods and storms or to evacuate them. Moreover, poor people are more vulnerable to natural disasters because they live in more hazardous locations, they have less protection, and have access to fewer reserves and insurances.

Furthermore, recent research has found a relationship between environmental degradation and security. Homer-Dixon (1999), for example, found that environmental scarcities are very likely to have profound social consequences - contributing to insurrections, ethnic clashes, urban unrest, and other forms of civil violence, especially in the developing world. Environmentally induced migration, in particular, seems to become a potential transmission mechanism between environmental degradation and conflict, as global climate change will force increasingly more people to leave their traditional habitats. 
As already stated above, climate change seriously threatens economic development in developing countries if no counter-measures are taken. The extent to which the impacts of climate change constrain economic development differs by region. Small island states lying only a few meters above sea level are in acute jeopardy as a result of climate change-induced sea-level rise (CSD, 2004). The same is true with regard to the large number of people living in coastal mega-cities. Other examples are countries where tourism represents a major source of income. They may be affected by a decrease in revenues due to the effects of both gradual climatic change and extreme weather events. All these linkages affect a country's GDP, balance of payments, state of public finance or its ability to attract foreign direct investment, all of which play a significant role in determining a country's long-term development.

\subsection{The nexus between energy, poverty and environment}

When it comes to energy use in developing countries, the facts speak for themselves: According to IEA (2002) estimates, some 1.6 billion people had no access to electricity in 2002, $80 \%$ of whom were living in rural areas of South Asia and sub-Saharan Africa. Some 1.4 billion people will still lack electricity in 2030. Approximately 2.5 billion people, roughly half of the population in developing countries, today still rely on traditional biomass for heating and cooking. In many developing countries wood, charcoal, agricultural waste and animal dung account for over $90 \%$ of household energy consumption (IEA, 2006).

At the same time, it is obvious that energy in the form of light, heat, mechanical power or electricity is essential in every society and plays a key role in the development perspectives of poor countries. Access to a modern energy is an important prerequisite for poverty reduction and the achievement of the MDGs. Even if there is no MDG directly related to energy, all eight MDGs depend on the poor having access to affordable and clean energy sources: energy underpins incomes, education, social participation, gender equality, health and sustainable use of natural resources. A lack of electricity exacerbates poverty and contributes to its perpetuation, as it precludes most industrial activities and the jobs they create. Empirical evidence shows the link between energy services and development: there appears to be a positive connection between a country's GNP per capita and modern energy use per capita as well as a correlation between a country's per capita energy consumption and its Human Development Index (HDI) as shown in Figure 1 (Karekezi, 2002; UNDP, 2005).

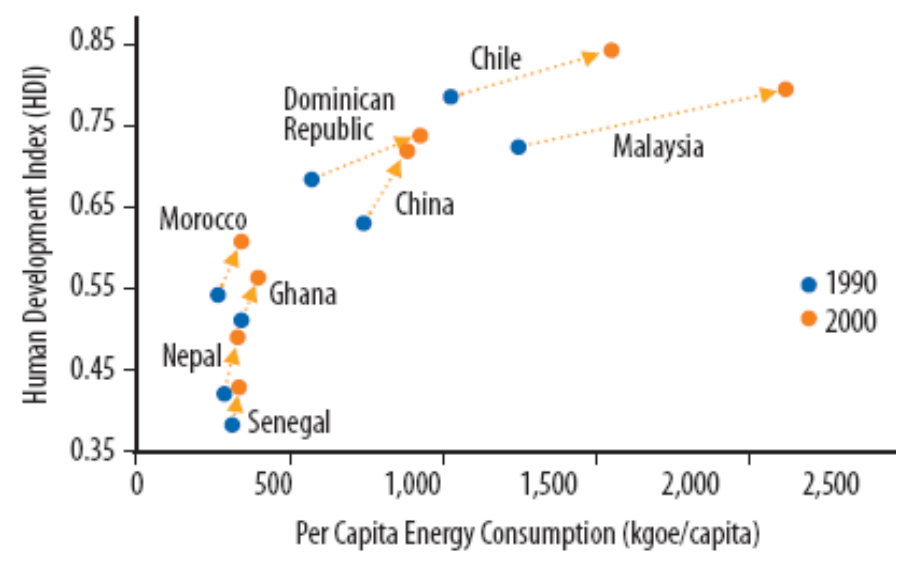

Figure 1: Relationship between $\mathrm{HDI}$ and energy consumption (UNDP, 2005)

When analyzing the impact of energy supply on poverty, the two forms of energy, fuels versus electricity, should be considered separately. While fuel is required for basic needs such as heating and cooking, electricity provides more "subordinated" necessities such as lighting, telecommunication and transport. The supply of affordable and clean fuels to the poor is therefore seen as a priority for action. The use of wood, coal, manure and agricultural waste for cooking and heating has many hazardous effects. According to WHO estimates, the combustion of these traditional biomass materials causes 1.5 million premature deaths every year. Indoor air pollution due to the use of traditional biomass materials accounts for more deaths than malaria. Respiratory diseases affect women and children in particular, as they spend a lot of time indoors doing the housework. Apart from these serious health related concerns, the use of traditional biomass for heating and cooking imposes another burden on the rural poor: time spent on gathering wood for fuel keeps women and children from participating in education and other beneficial activities. Furthermore, it exhausts them physically since in order to collect enough material they must often spend many hours on their feet. Modern energy sources are therefore needed to provide such people the time necessary for children to go to school, thereby upgrading the labor force for income-generating activities. In addition, the use of coal and traditional biomass as energy sources leads to environmental concerns. Charcoal production can lead to land and forest degradation and the removal of dung and agricultural residuals from the fields may reduce soil fertility and result in erosion. Modern cooking fuels such as liquid petroleum gas (LPG), kerosene or biofuels like ethanol and methanol are less likely to harm people and the environment. Hazardous situations may also be avoided by introducing improved stoves and better ventilation systems (IEA, 2006). 
Electricity, in contrast, is particularly essential for smallscale industries and agriculture as it provides new and more cost-efficient production techniques, new irrigation potentials and extended working hours. Renewable energy sources, such as modernized biomass, solar photovoltaic, wind or hydrogen, offer an attractive, cost-efficient alternative to traditional energy sources, especially in remote rural areas. Estimates by Deepchand (2001) indicate that a significant proportion of current electricity generation in 16 Eastern and Southern African countries could be met by bagasse-based cogeneration in the region's sugar industry. In addition, although there is enormous capacity for exploitable hydropower in African countries, less than seven percent has been harnessed one of the world's lowest figures (Karekezi, 2002). If more effort were made to tap into this valuable resource, the lives of many people would be greatly improved. After all, electricity serves to illuminate homes and schools, enables modern radio- and telecommunication and thus access to medical care, health information and transport services, these being all important prerequisites for the wellbeing and productivity of individuals (UNDP, 2005). 


\section{Reducing poverty through climate and energy policy}

3.1 Mainstreaming and integrating policies

Due to the predictable and serious impacts of environmental changes to the livelihoods of poor groups in the developing countries, further human intervention in the natural environment must be avoided and adaptation measures should be intensified. The strong links between energy use, environment and poverty should be mobilized for development policy. However, it should be kept in mind that accelerated income growth in developing countries may entail an increase in carbon dioxide emissions and could therefore aggravate environmental threats. Empirical evidence shows that carbon emissions rise with a country's average income. This implies a trade-off between raising average living standards and setting limits on global warming. Yet, there is also evidence that the marginal propensity for carbon emissions declines with rising income, which in turn is an argument to reduce global inequality in order to limit global warming (Ravallion et al., 2000; IPCC, 2001b). The latter fact could indicate that with rising income, energy efficiency and demand for the protection of the environment increase, as Dasgupta et al. (1995) found out. The challenge lies in linking environmental, energy and development policy in a way that enables a "triple dividend" for all three policy fields. Various policy options can act as an important lever in poverty reduction, transformation of energy systems and environmental protection:

a) Strengthening the environment-energy-poverty nexus in Official Development Assistance

The traditional sectoral approach of development cooperation appears to be unable to efficiently address environmental, energy and development concerns because most environmental threats require a cross-sectoral approach. Climate change action, for example, is directly linked to various policy fields like energy, industry, transport, forest management, agriculture, waste management, water, land and coastal zone management. An integrated cross-sector policy would therefore better address the complexity of the problem and generate synergies (OECD, 2002). Environmental projects with a clear poverty focus can be identified in the field of water supply, basic sanitation, modern energy supply, energy efficiency, disaster protection, waste disposal services, natural resource management and reduction of vectorborne diseases (Bucknall et al., 2000). Furthermore, WBGU (2005) recommends that disaster prevention and adaptation to expected global environmental change should become new priorities in development cooperation. The corresponding sector policies should take account of all these aspects and be adapted to the overall goal of poverty reduction and environmental sustainability. b) Mainstreaming and integrating environmental and energy concerns in the planning and budgeting process of national governments

After the Johannesburg Earth Summit in 2002, the United Nations Development Programme (UNDP) and the United Nations Environment Programme (UNEP) established strategies to mainstream environmental and energy concerns into national government's planning and budgeting processes. Their intention was for the so called Rio Conventions to be integrated into national policies, plans and programmes. These conventions conceived in the run-up to the 1992 Rio Conference (Rio Conventions), notably the United Nations Framework Convention on Climate Change (UNFCCC), the Convention on Biological Diversity (CBD) and the United Nations Convention to Combat Desertification (UNCCD), all provide financing mechanisms as well as measures for technology transfer and capacity building. As mentioned before, ongoing climate change, lack of biological diversity and desertification increase the vulnerability of the poor. The challenge is to integrate these financing and capacity building mechanisms with the national action plans, for example with the national Poverty Reduction Strategies (PRSs) (OECD, 2002). Governments of developing countries today predominantly treat energy and environment in separate sector policies. It is therefore crucial to raise awareness among government officials that energy and environment concerns have direct links to productivity and growth and that stronger collaboration and information exchange between different departments and ministries is needed (UNDP, 2005).

\section{c) Strengthening international mechanisms to mitigate climate change}

Another important lever for poverty reduction through environmental policy is the mitigation of global climate change by making efforts to reduce the emission of greenhouse gases. This is possible by trading emission certificates on a global carbon market as well as boosting energy efficient technologies and renewable energy sources.

\section{d) Reducing developing countries' vulnerability through financing adaptation to climate change}

In addition, the global community should help to reduce the vulnerability of poor people in developing countries through financing adaptation to climate change. Most adaptation measures have a clear poverty impact, for example improved resilience of housing and infrastructure to natural disasters, increased food security through enhanced agricultural cultivation techniques and improved governance, especially in the field of natural resource management (UNDP et al, 2003). 


\subsection{Mitigating climate change through the Kyoto mechanisms}

In order to protect developing countries against the most damaging consequences of climate change the world community has to increase its efforts to reduce carbon emissions. If until 2050 the world community arrives at reducing global anthropogenic greenhouse gas (GHG) emissions by half compared to emissions in 1990, an increase in global mean surface temperature over $2^{\circ} \mathrm{C}$ may still be prevented. The damages associated with a temperature rise above $2^{\circ} \mathrm{C}$ range from food and water scarcity to hazards through extreme weather events like storms and flooding and endanger the livelihood of the poor (see section 2) (WBGU, 2006). Developing countries thus benefit strongly from emission reductions on the longer term.

A first step to reduce global GHG emissions was taken with the adoption of the Kyoto Protocol at the Third Session of the Conference of the Parties to the United Nations Framework Convention on Climate Change (UNFCCC) in December 1997. Following Russia's decision to ratify the Kyoto Protocol, it came into force on 16 February 2005 and sets binding numerical targets for the limitation and reduction of greenhouse gas emissions for the industrial and transition countries during the period 20082012. The market-based Clean Development Mechanism (CDM) serves as a tool to integrate developing countries into the global carbon market and to promote sustainable development simultaneously through the transfer of new technologies and know-how to developing countries.

The overall rationale of the Clean Development Mechanism (CDM) is that CDM projects lead to GHG emission reductions while having the potential to accelerate sustainable development simultaneously. This presumes that the projects have a strong poverty focus, which is not always the case. This is one of the reasons why poverty effects of CDM projects are still viewed with skepticism. Since 1997 some 200 studies on the CDM have been conducted to evaluate if they fulfilled their objective to link greenhouse gas emission reduction with sustainable development. It was shown that this was not always the case (Holm Olsen, 2006).

One major problem lies in the institutional design of the CDM itself. The mechanism is intended to achieve cost-effective reduction of carbon emissions for countries participating in the global carbon market. It comes as no surprise that investors tend to realize CDM projects that reduce $\mathrm{CO}_{2}$ emissions in the cheapest and most costeffective way, while minimizing risks. As the ancillary benefits for sustainable development are not valuated on the carbon market, investors have no incentive to take poverty issues into account. In fact, the CDM requires the appointment of a Designated National Authority (DNA) to set and monitor sustainability standards for CDM projects in their respective country. However, theses standards can vary strongly by country and they depend on the development priorities of the respective countries. In order to attract as many CDM projects as possible, the DNAs may be tempted to hold sustainability standards down. It can be concluded that the institutional construction of CDM tends to lead to a trade-off between GHG emissions reduction and the realization of development targets rather than serving the initially intended "win-win"approach (Holm Olsen, 2006).

The bias of realized CDM projects away from propoor projects towards cheap and low-risk investments is also reflected by the geographical spread of CDM projects. $46.2 \%$ out of 489 projects registered by UNFCCC in January 2007 are located in Latin America and the Caribbean, $50.1 \%$ in Asia and the Pacific. The four transition economies of India (155), Brazil (88), Mexico (73) and China (36) together account for $72 \%$ of all presently registered CDM projects. Only $2.7 \%$ of all registered projects are located in Africa (see Figure 2; UNFCCC, 2007). Long organizational and administrative processes, long payback periods and specific project risks constrain the activities of potential investors in the least developed countries. Of course, the risks investors usually face in developing countries with poor institutions prevail. It is evident that LDCs need significant ODA support in order to secure the realization of win-win-projects. The World Bank's Community Development Carbon Fund, a publicprivate initiative operational since March 2003, tries to fill this gap by supporting emission reduction projects with a clear poverty impact in LDCs, especially in Sub-Saharan Africa. According to World Bank observations the relatively low number of projects in Africa is also due to the limited fossil fuel-related GHG emissions, given the lack of large energy sectors and manufacturing industries in African countries. Land use and forestry projects, as far as eligible under the CDM, rural electrification projects and the promotion of clean energy could instead make a significant contribution to poverty reduction in SubSaharan Africa (Richards, 2003; World Bank, 2006).

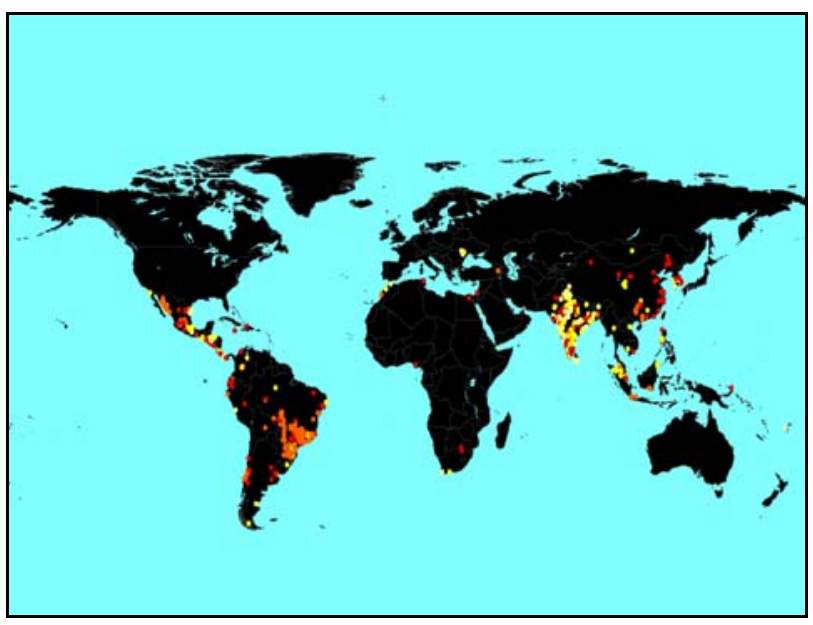

Figure 2: Geographical spread of registered CDM projects (UNFCCC, 2007) 
In order to ease the inherent conflict of interests within the CDM, the World Wide Fund for Nature (WWF) recently developed the idea of the "CDM Gold Standard", which aims to ensure that certain sustainability criteria are met. Concepts like the "CDM Gold Standard" can be seen as an attempt to label high quality CDM projects and may be a policy option to guide CDM investments to more poverty relevant projects. CDM projects with a high sustainable development dividend are, for example, those that improve energy efficiency and promote renewable energies as well as community forestry projects (Richards, 2003). So far, the majority of CDM projects have been concentrated in the field of end-of-pipe options (e.g. Fluorinated gases- or landfill gas-projects) with no direct development impact (IISD, 2005). Obviously this has changed, as to date CDM projects in the energy industry achieve a proportion of $47.5 \%$ among all registered CDM projects (January 2007, UNFCCC).

\subsection{Improving access to advanced energy in developing countries}

Transforming the energy systems in the poor and vulnerable regions of the world is a very effective strategy to serve both environmental protection and poverty eradication. As mentioned, CDM projects in the energy sector rank among the projects with the highest development dividend. It is of utmost importance to safeguard and expand access to modern forms of energy in developing countries and thus to eradicate energy poverty worldwide. This is a fundamental contribution to poverty reduction. The attainment of the Millennium Development Goals is determined critically by questions of energy supply. Particular challenges are presented by the switch from health-endangering biomass use for cooking and heating to modern energy carriers, and the provision of energy services that depend upon access to electricity. All measures undertaken to transform energy systems should take care to reduce regional and socioeconomic disparities. Disadvantaged groups need to be supported and special cultural or gender-specific aspects should be taken into account (WBGU, 2005).

The effectiveness of energy technology-based emission reduction strategies will depend importantly on the rates of diffusion of the respective technologies. Regional assessments by GNESD (2006) on the dissemination of renewable energy technology (RET) in developing countries show that the barriers to adoption of new technologies for poor households and small enterprises are numerous. Among them are high initial investment costs, lack of qualified personnel for installation and maintenance of the technologies and inadequate information of the population about applicability of new technologies and their potential for cost-efficient production in small businesses. Chaurey et al. (2004) also mention that the distribution of technology itself will not contribute significantly to poverty reduction if it is not accompanied with maintenance support and activities that stimulate income generation.

To overcome these problems, new financing schemes need to be developed and information policies should be set up by the governments. During the introduction phase systematic subsidization of the new technologies can be an effective policy option to address the problem of high upfront costs (IEA, 2002; Chaurey et al., 2004). When installing new technologies, ownership and participation of the population play a crucial role: lacking responsibility of the population reduces acceptance and may lead to vandalism. A successful strategy to disseminate RETs in developing countries could prepare the ground for new employment in the field of manufacturing and maintenance of the new technologies as well as in the field of resource extraction and processing. It could also drive further income-generating activities (GNESD, 2006; IEA, 2002).

\subsection{Promoting adaptation to reduce vulnerability}

As already mentioned, measures to reduce GHG emissions are indispensable in order to protect poor people from the damages of climate change and environmental degradation. However, the effects of mitigation policies will only make an impact by mid-century or even later. It is therefore equally important that the world community acts in the short term if it wants to reduce poor people's vulnerability. Adaptation measures should be taken immediately. The Poverty Reduction Strategies (PRSs) currently being pursued must be revised in anticipation of the likely regional impacts of global environmental changes. There is no doubt that adaptation measures like climate resistant housing, disaster prevention and relief, new infrastructure and improved agricultural cultivation techniques protect the income of the poor in a concrete and direct manner. Richards (2003) describes adaptation therefore as the "key poverty issue surrounding climate change".

According to development policy makers, the main fields for adaptation measures are good governance, human resources, institutional structures, public finance and natural resource management (UNDP et al., 2003). Facing an increase in extreme weather events, disaster preparedness and disaster relief are also important fields of action. For the planning of risk prevention schemes, risk and vulnerability assessments are urgently needed (WBGU, 2005; Richards, 2003). Agriculture and forestry are also important fields where adaptation measures have to be taken. An agricultural system which is robust enough to withstand global environmental changes must promote a diversity of cultivation systems and plant species (also in order to cushion the impacts of climate-induced blights and infestations). It must be able to cope with the stresses 
caused by drought, intense heat or salinization (WBGU, 2005)

Efficient financial instruments such as weather derivatives or disaster loans could be considered to overcome the hardships not covered by insurance or similar institutions. In addition to the successful microcredit schemes already introduced, the launch of microinsurance schemes for the purpose of risk spreading in the event of individual hardship (e.g. illness) should also be considered as an element of risk management. These microfinance schemes should be integrated with existing banking and insurance systems to a greater extent and additional funding should be provided for them (WBGU, 2005). The promotion of environmentally relevant spatial planning as part of development cooperation is strategically important, as well as the development and enforcement of effective environmental laws and the production of national environmental statistics (WBGU, 2005).

All in all, there is much common ground between climate change adaptation and poverty reduction. Increasing the resilience of livelihoods and infrastructure are key components of an effective poverty reduction policy. Capacity building, empowerment and good governance also provide the basis for the reduction of poor countries' vulnerability. For the success and effectiveness of adaptation measures, it is essential that they are appropriate for the local conditions and accepted by local stakeholders. In a bottom-up approach, local and regional knowledge should therefore be harnessed for the planning of policy measures (UNDP et al., 2003).

\subsection{Positive feedback of poverty reduction on environmental protection}

The feedback loops presumably existing between environmental degradation and poverty allow for the assumption that poverty reduction has positive effects on the over-exploitation of natural resources. However, according to WBGU (2005) the significance of poverty's negative impacts on the natural environment is often overestimated - prosperity and industrialization play a far greater role in causing environmental change. This is in line with findings of Duraiappah (1998) who states that a direct poverty-environment-nexus does not have sufficient support in empirical studies. Yet, it can be observed that people who subsist from agriculture and forestry tend to overuse their natural resources. Food shortage, for example, can bring about the need for rapid conversion of available lands to monocrop agriculture, excessive water use for irrigation and the application of chemical fertilizers. In part, overuse of natural resources may also be due to institutional and market failures, manifesting themselves in the lack of property rights and land tenure or in unsustainable government policies (e.g. subsidies on unsustainable cultivation techniques). Many ecosystem goods are not marketed in developing countries and are available at no cost to the user. This encourages land use changes such as deforestation for intensive agricultural production. Apart from over-exploitation of natural resources, the absence of modern sanitation systems in developing countries often leads to water and soil degradation. When waste is deposited in natural ecosystems and their capacity of absorption and selfcleansing is exceeded, the inevitable consequence is contamination of water and soil resources (Duraiappah, 1998; OECD, 2002).

Fighting poverty through better provision of basic services, enhanced rights of participation and entitlements along with better income-generation opportunities can in reverse reduce the pressure on local ecosystems. Thus, positive feedback effects from poverty reduction on the environment can be expected. However, poverty reduction measures should include advancements in capacity building for good governance, the creation of stable institutions and a system of guaranteed property rights to overcome market failures. An increase in participation of the local population, empowerment of women and the improvement of the critical infrastructure (energy supply, waste management, etc.) are also prerequisites for a sustainable use of natural resources. Improved infrastructure in turn depends strongly on the promotion of technological change. 


\section{$4 \quad$ Financing climate change and sustainable development}

To assist the developing countries in bearing climate change impacts the international community launched special adaptation funds with different objectives. The GEF Trust Fund, for example, concentrates on adaptation measures that lie in the focal areas of GEF funding, e.g. biological diversity, climate change, international waters, land degradation and others. The UNFCCC Special Climate Change Fund (SCCF) specializes in the development areas most affected by climate change (e.g. water, land, agriculture, health and others), while the UNFCCC Least Developed Countries (LDCS) Fund focuses on the development of so called National Adaptation Programmes of Action (NAPAs) in especially poor countries. The so called Kyoto Protocol (KP) Adaptation Fund, which is not yet operational, will provide funding for adaptation measures in particularly vulnerable Parties to the Kyoto Protocol (UNFCCC, 2006; GEF, 2006).

Contributions to the funds are voluntary. Altogether these funds make available financial resources amounting to some hundred million USD. On the opposite, transfer needs from industrial to developing countries in order to achieve the Millennium Development Goals by 2015 are estimated to lie between 40,000 to 70,000 million USD annually (WBGU, 2005; Devajaran et al., 2002; UN, 2001, 2004). The existing funds therefore need to be further expanded to effectively promote adaptation. The KP Adaptation Fund will partly be financed from a $2 \%$ levy on Certified Emission Reductions (CERs) issued for CDM project activities, which can be seen as a competitive disadvantage for the Clean Development Mechanism. Rather would it be desirable to expand the levy on all Kyoto mechanisms.

To enable individuals to cope with climate change impacts, innovative financing instruments such as microcredits and microinsurances should be supported through development cooperation and strengthened institutionally. Lost agricultural crop yields due to extreme and harmful weather variations could be offset through index-based microinsurances. As proposed in section 3.4 innovative risk spreading instruments such as weather derivatives or disaster loans should be further promoted (UNEP FI, 2006; WBGU, 2005).

Regarding the financing of climate mitigation measures, private enterprises have to bear the majority of the costs by curbing down their own carbon emissions and by investing in CDM projects. Besides, there is also institutional financing of mitigation measures, such as the already mentioned World Bank Community Development Carbon Fund (see section 3.3), which aims at guiding more CDM projects into the LDCs. To ensure that the least developed countries also gain from the global mitigation efforts, this fund should be further supported by industrial countries (IISD, 2005).

\section{Conclusions}

We conclude that environmental, energy and development policies should not be treated separately but in an integrated manner. The interrelations between the policy fields are too strong to be neglected and the potential synergies too great to be left untapped. One major conclusion we draw is that developing as well as developed countries will profit from the proposed approach. Positive effects on the state of the environment and the economies of both industrial and developing countries can be expected. First of all, global environmental problems such as climate change can be limited in all parts of the world. Poor countries will especially profit from reduced local environmental devastation such as soil degradation or water and air pollution (environment dividend). At the same time, improved environmental quality will directly contribute to poverty reduction in the developing world and reduce the vulnerability of the affected people (poverty reduction dividend). Through the mainstreaming of environmental issues into poverty reduction policies developing countries could also profit economically and ecologically from a so called 'technology dividend,' when development aid is used for a fast and easy adoption of new technologies.

The greater the success of environmental and poverty reduction goals in developing countries, the smaller the need for North-South transfers in the future. For the industrial countries new export markets would arise if the developing countries gained weight in the world economy. In developing countries reducing poverty and environmental degradation creates new opportunities for productive activities and employment and makes these countries more attractive for foreign direct investment (growth dividend). Finally, by maintaining natural lifesupport systems and successfully reducing poverty, the numbers of refugees fleeing from environmental degradation and poverty will decrease. This could lessen the industrial countries' concerns about unwanted immigration and reduce costs, e.g. for deterring measures. Improved living conditions, stronger entitlements and enhanced participation rights in the developing countries will narrow the enabling environment for terrorism (security dividend). 


\section{References}

Bucknall, J., Kraus, C., and Pillai, P. (2000). Poverty and Environment: Background Paper for the World Bank Environment Strategy. Washington: The World Bank.

Campbell-Lendrum, D.H., Corvalan, C., Ebi, K., Githenko, A., Scheraga, J. and Woodward, A. (eds.) (2003). Climate Change and Health. Risks and Responses. Geneva: WHO.

Chaurey, A. et al. (2004). "Electricity Access for Geographically Disadvantaged Rural Communities Technology and Policy Insights." Energy Policy 32: 16931705 .

CSD (2004). Review of Progress in the Implementation of the Programme of Action for the Sustainable Development of Small Island Developing States. Report of the Secretary-General. UN Document E/CN.17/2004/8. New York: CSD.

Dasgupta, S. et al. (1995). Environmental Regulation and Development: A Cross-country Empirical Analysis. Policy Research Working Paper 1448. Washington: The World Bank.

Deepchand, K. (2001). Bagasse-based Cogeneration in Mauritius - A Model for Eastern and Southern Africa. Occasional Paper No. 2, Nairobi: AFREPREN/FWD.

Devajaran, S. et al. (2002). Goals for Development. History, Prospects and Costs. Washington: The World Bank.

Duraiappah, A.K. (1998). "Poverty and Environmental Degradation: A Review and Analysis of the Nexus." World Development 26(12): 2169-2179.

GEF (2006). Status Report on the Climate Change Funds. Prepared for the GEF Council, 6-9 June 2006. (http://thegef.org/Documents/Council_Documents/G EF_C28/documents/C.28.4.Rev.1ClimateChange.pdf, accessed on 22 January 2007).

GNESD (2006). Poverty Reduction - Can Renewable Energy Make a Real Contribution? Summary for Policy Makers. GNESD.

Holm Olsen, K. (2006). The Clean Development Mechanism's Contribution to Sustainable Development: A Review of the Literature. ReNED.

Homer-Dixon, T.F. (1999). Environment, Scarcity and Violence. Princeton, Oxford: Princeton University Press.

IEA (2002). World Energy Outlook 2002. Paris: IEA.

IEA (2006). World Energy Outlook 2006. Paris: IEA.

IFRC (2002). World Disasters Report 2002. Geneva: IFRC.
IISD (2005). Realizing the Development Dividend: Making the CDM Work for Developing Countries. Phase 1 Report.

IPCC (ed.) (2001a). Climate Change 2001: Impacts, Adaptation, and Vulnerability. Contribution of Working Group II to the Third Assessment Report of the IPCC. Cambridge, New York: Cambridge University Press.

IPCC (ed.) (2001b). Climate Change 2001: Mitigation: Contribution of Working Group III to the Third Assessment Report of the IPCC. Cambridge, New York: Cambridge University Press.

Karekezi, S. (2002). "Poverty and Energy in Africa - A brief Review." Energy Policy 30: 915-919.

OECD (2001). OECD Environmental Strategy for the First Decade of the 21st Century. Paris: OECD. (http://www. oecd.org/dataoecd/33/40/1863539.pdf, accessed on 22 January 2007)

OECD (2002). The DAC Guidelines - Integrating the Rio Conventions into Development Cooperation. Paris: OECD.

Ravallion, M., Heil, M., Jalan, J. (2000). Carbon Emissions and Income Inequality. Oxford Economic Papers 52: 651-669.

Richards, M. (2003). Poverty Reduction, Equity and Climate Change: Global Governance Synergies or Contradictions? Globalisation and Poverty Programme. Overseas Development Institute (ODI).

UN (2000). The Millennium Declaration of the United Nations. New York: UN.

UN (2001). Zedillo-Report of the High-Level Panel on Financing for Development. New York: UN.

UN (2004). We the Peoples: Civil Society, the United Nations and Global Governance. Report of the CardosoPanel of Eminent Persons on United Nations-Civil Society Relations. New York: UN.

UNDP et al. (2003). Poverty and Climate Change: Reducing the Vulnerability of the Poor through Adaptation.

UNDP (2005). Energizing the Millennium Development Goals - A Guide to Energy's Role in Reducing Poverty. New York: UNDP.

UNEP Finance Initiative (2006). Adaptation and vulnerability to climate change: The role of the finance sector. CEO Briefing, November 2006.

UNFCCC (2006). Overview of existing programmes and policies to assist adaptation activities. Background paper for the UNFCCC Workshop on the Adaptation Fund in Edmondon, Canada, 3-5 May 2006. (http://unfccc.

int/files/cooperation_and_support/financial_mechani 
Schubert et al.: Environmental protection, energy policy and poverty reduction - synergies of an integrated approach

sm/adaptation_fund/application/pdf/overview_of_fu nding_for_adaptation.pdf, accessed on 22 January 2007).

UNFCCC (2007). CDM Statistics. (http://cdm.unfccc.int/ Statistics, accessed on 22 January 2007)

WBGU (2005). World in Transition: Fighting Poverty through Environmental Policy. German Advisory Council on Global Change (WBGU). London: Earthscan. [German version published in 2004]

WBGU (2006). The Future Oceans - Warming Up, Rising High, Turning Sour. Special Report 2006. Berlin: WBGU.

WHO (2001). Macroeconomics and Health: Investing in Health for Economic Development. Report of the Commission on Macroeconomics and Health. Geneva: WHO.
WHO (ed.) (2002). The World Health Report 2002. Reducing Risks and Promoting Healthy Life. Geneva: WHO.

World Bank (2000). Fuel for Thought: An Environmental Strategy for the Energy Sector. Washington: The World Bank.

World Bank (2006). Submission on Regional Distribution of CDM Project Activities to the Members of the CDM Executive Board. (http://carbonfinance.org/docs/ CDM_Regional_Balance_EB_call_for_input.pdf, accessed on 22 January 2007 )

WRI (2003). World Resources 2002-2004. Oxford, New York: Oxford University Press. 

ETH Zurich

Institute for Environmental Decisions IED

WEH G 9

CH-8092 Zurich

SWITZERLAND

Phone +41446324718

Fax +41446321042

URL http://www.ied.ethz.ch 